\title{
Genomic studies of biological soil crusts - successional dynamics for the rehabilitation of mine tailings facilities
}

\author{
CA Ortiz Universidad de Santiago de Chile, Chile \\ M Wilkens Universidad de Santiago de Chile, Chile \\ AP Muñoz Universidad de Santiago de Chile, Chile \\ D Fernández Universidad de Santiago de Chile, Chile \\ F Muñoz Universidad de Santiago de Chile, Chile
}

\begin{abstract}
Biological Soil Crusts (BSCs) are complex communities that include primary producers and multiple levels of consumers in the dependent food web generally consisting of hundreds of species. BSCs can increase porosity, enhance aggregate stability and improve physical structure of soils. Furthermore, BSCs protect soils from wind and water erosion, and they have been used in desertification control. Cyanobacteria are the principal live component of BSCs and provide most of the cohesive characteristics of the BSCS in arid and semi-arid lands by the production and secretion of polysaccharides that allow the chelation and bioavailability of nutrients for other organisms such as algae, fungi and other bacteria species. The microorganisms that are present in the BSCs are not easy to grow using traditional methods; hence, studies using molecular techniques can help to examine the wide range of microorganisms present in the communities. Due to the environmental features of the BSCs, it has been suggested that they can be used to bioremediate degraded soils for rehabilitation purposes. We conducted the first study carried out in Chile in order to develop a methodology for the use of biocrusts as the primary stabilisation means for both soil stockpiles and rehabilitated soil. The phylogenetic and diversity characterisation of BSCs through genomic analysis and bioinformatic tools will allow the development of a suitable methodology to culture and then to inoculate the communities of microorganisms on soils for mine site reclamation.
\end{abstract}

\section{Introduction}

Biological Soil Crusts (BSCs) are a complex and intimate association between soil particles and microorganisms such as cyanobacteria, algae, lichens, mosses, fungi and bryophytes (Belnap \& Lange 2003). BSCs generally consist of hundreds of species, including producer microorganisms such as cyanobacteria (blue algae), symbionts and multiple levels of consumers in the dependent food web (Bowker et al. 2010). These microorganisms are capable of forming associations with soil particles conferring to the substrate cohesion and stability. They also improve the soil fertility and play an important role in the germination, growth and survival of native species of plants (Zaady et al. 1997) However, their morphological variability, heterogeneity and community composition are still poorly known and require a thorough revision (Komárek et al. 2013). BSCs in arid and semi-arid conditions constitute a dominant biotic component and can regulate the soil surface (Belnap \& Lange 2003). BSCs are related to the control of local hydrological cycle, the improvement of the physical structure of soil and soil erosion reduction (Zhang 2006; Belnap \& Gillete 1998), and they have been used in desertification control (Wei 2005). BSCs play an important role in the biogeochemistry of elements modulating the carbon cycle (Maestre \& Cortina 2002) and the nitrogen cycle (Castillo-Monroy et al. 2010) and are considered responsible for the autotrophic carbon and nitrogen fixation in drylands (Bowker et al. 2011). 
The cohesive characteristics of BSCs in arid and semi-arid lands are provided by the polysaccharides producing Cyanobacteria component that allow the chelation and bioavailability of nutrients to other microorganisms (García-Pichel \& López 2001; Lin et al. 2013).

Biocrusts are a good example of micro-landscapes, which exhibit heterogeneity, aggregation, connectivity and fragmentation like macro-landscapes, but little is known about the composition of these communities and their relationships with physicochemical properties of soils. Studies about communities using genomic techniques can help to examine the wide range of microorganisms present in the communities (Bowker \& Maestre 2014). The BSCs can be classified as young crusts or mature crusts depending on the successional stage of the development they present (constituent species diversity, fixation rates of elements, colour etc.). Young crusts are considered as those that have a poor development (below 10 years) and mature crusts as those that take more time (from decades to centuries) (Yeager et al. 2004). Mature BSCs have higher water retention capacity, are more resistant to erosion, present higher biomass, amount of DNA, chlorophyll-a and nitrogen fixation than those in a newest state. This is because they present a variety of constituent species. While the BSCs in a young successional stage are typically dominated by cyanobacteria such as Microcoleous vaginatus, mature crusts contain other varieties of cyanobacteria like Nostoc and Scytonema spp.

Since the BSCs develop on the soil surface, and the microorganisms present on them are not easily cultivated, molecular techniques are a useful tool for a complete characterisation of the microbial composition of these communities. These techniques offer the possibility of detecting species in diverse environments that are not detected by conventional techniques, with the purpose of studying the microbial diversity and microbial ecology without culturing the microorganisms. Molecular studies are based on the analysis of nucleic acids extracted directly from environmental samples or from cultures, and the identification of the microbial components using molecular markers for the phylogenetics classification (Valentini et al. 2009). The molecular markers used to identify microorganisms present in environmental samples are $16 \mathrm{~S}$ ribosomal Ribonucleic Acid (rRNA) genes for identification of cyanobacteria and nif gene for the identification of nitrogen-fixing bacteria (Bérard \& Dorigo 2004), 18S rRNA gene for identification of eukaryotes like algae (Rodicio \& Mendoza 2004), and ITS sequence (Internal Transcribed Spacer), which is a non-coding and spacer DNA situated between the small-subunit ribosomal RNA for fungi (Schoch et al. 2012). In this study, we evaluated the microbial composition of samples of BSC from six sites in two different locations at the Fourth Region of Coquimbo located in the North of Chile and characterised as a semi-arid environment. The physicochemical characteristics of the soil samples were studied in order to establish a relationship between the quality of the soil samples and the developmental stage of the BSC. We propose that BSCs isolated from this type of environment can contribute to the rehabilitation of mining sites located in the North of Chile as a first step of biological colonisation followed by the establishment of other species such as non-vascular plants, as it has been proposed by Eldridge (1996) and Bowker (2007).

\section{$2 \quad$ Methods}

\section{$2.1 \quad$ Sampling}

The study area included six sampling sites named as sites $A, B, C, D, E$ and $F$ in the Coquimbo region of Chile. Three sites $(A, B$ and $D)$ were located to the north of the region and three sites $(C, E$ and $F)$ were about $160 \mathrm{~km}$ south (Table 1, Figure 1). The locations A, B and D present a coastal climate, which is characterised by clouds, moderate temperatures and humidity; and the locations $\mathrm{C}$, $\mathrm{E}$ and $\mathrm{F}$ correspond to a temperate steppe climate. Soil samples were collected in sterile Falcon tubes from the first centimetre of the surface of the soil. Table 1 shows the number of samples collected per site and the geographical location of the site. Discrete subsamples from adjacent sampling points, evenly spaced, and composited laterally, were collected in an area of similar size and shape, except where it was not geographically possible. A maximum of six discrete constituents were included in each composite sample. Each discrete subsample was thoroughly homogenised before stored in sterile bags and maintained at $4^{\circ} \mathrm{C}$ for further analysis. 
Table 1 Sample identification, number of samples collected and coordinates of each site

\begin{tabular}{ccc}
\hline Site & $\begin{array}{c}\text { Number of samples } \\
\text { collected }\end{array}$ & Coordinates \\
\hline A & 11 & $29^{\circ} 19^{\prime} 28.83^{\prime \prime} \mathrm{S}, 71^{\circ} 14^{\prime} 1.59^{\prime \prime} \mathrm{O}$ \\
\hline B & 3 & $29^{\circ} 14^{\prime} 22.12^{\prime \prime} \mathrm{S}, 71^{\circ} 26^{\prime} 10.82^{\prime \prime} \mathrm{O}$ \\
\hline C & 7 & $30^{\circ} 41^{\prime} 52.23^{\prime \prime} \mathrm{S}, 71^{\circ} 1^{\prime} 58.1^{\prime \prime O} \mathrm{O}$ \\
\hline D & 3 & $29^{\circ} 18^{\prime} 34.47^{\prime \prime} \mathrm{S}, 71^{\circ} 16^{\prime} 16.53^{\prime \prime} \mathrm{O}$ \\
\hline E & 3 & $31^{\circ} 0^{\prime} 26.36^{\prime \prime} \mathrm{S}, 70^{\circ} 52^{\prime} 32.03^{\prime \prime} \mathrm{O}$ \\
\hline F & 7 & $30^{\circ} 47^{\prime} 19.43^{\prime \prime} \mathrm{S}, 70^{\circ} 49^{\prime} 9.33^{\prime \prime} \mathrm{O}$ \\
\hline
\end{tabular}



Figure 1 Geographic localisation of sampling sites

\subsection{Extraction, amplification and sequencing}

Cell lysis and extraction of DNA were performed according to the manufacturer's specifications with the FavorPrep $^{\mathrm{m}}$ Soil DNA Isolation Minikit. DNA samples were maintained at $-20^{\circ} \mathrm{C}$. Quantification was performed in a multi-detector microplate reader Synergy ${ }^{\mathrm{Tm}} \mathrm{HT}$ of Biotek instruments according to manufacturer's specifications. Quantifications were made through absorbance of DNA at wavelengths 
260 and $280 \mathrm{~nm}$. PCR amplifications were performed using a G-Storm GS482 thermocycler, using specific primers to identify cyanobacteria, nitrogen-fixing bacteria, fungi and algae (Table 2).

Table 2 PCR amplification protocols

\begin{tabular}{|c|c|c|c|c|}
\hline \multirow{2}{*}{$\begin{array}{c}\text { Organism } \\
\text { Cyanobacteria }\end{array}$} & \multirow{2}{*}{$\begin{array}{c}\text { Sequence (5'-3') } \\
\text { GGGGAATYTTCCGCAATGGG }\end{array}$} & \multicolumn{2}{|c|}{ Thermal program } & \multirow{2}{*}{$\begin{array}{c}\begin{array}{c}\text { Size of } \\
\text { fragment }\end{array} \\
450 \mathrm{bp}\end{array}$} \\
\hline & & $94^{\circ} \mathrm{C} 2$ minutes & & \\
\hline & & $94^{\circ} \mathrm{C} 1$ minute & 4 cycles & \\
\hline \multirow[t]{6}{*}{ (16S) } & GACTACAGGGGTATCTAATCCCTTT & $\mathrm{n}^{\circ} \mathrm{C} 1$ minutes & $(n=46-47-48-49)$ & \\
\hline & & $72^{\circ} \mathrm{C} 1$ minute & & \\
\hline & & $94^{\circ} \mathrm{C} 1$ minute & 31 cycles & \\
\hline & & $50^{\circ} \mathrm{C} 1$ minute & & \\
\hline & & $72^{\circ} \mathrm{C} 1$ minute & & \\
\hline & & $72^{\circ} \mathrm{C} 15$ minutes & & \\
\hline \multirow{3}{*}{$\begin{array}{l}\text { Nitrogen-fixing } \\
\text { bacteria }\end{array}$} & TGCGAYCCSAARGCBGACTC & $94^{\circ} \mathrm{C} 5$ minutes & & $360 \mathrm{bp}$ \\
\hline & & $94^{\circ} \mathrm{C} 1$ minute & & \\
\hline & ATSGCCATCATYTCRCCGGA & $55^{\circ} \mathrm{C} 1$ minute & 30 cycles & \\
\hline \multirow[t]{2}{*}{ (Genes nif) } & & $72^{\circ} \mathrm{C} 2$ minutes & & \\
\hline & & $72^{\circ} \mathrm{C} 15$ minutes & & \\
\hline \multirow[t]{2}{*}{ Fungi } & TCCGTAGGTGAACCTGCGG & $94^{\circ} \mathrm{C} 5$ minutes & & $500-800 \mathrm{bp}$ \\
\hline & & $94^{\circ} \mathrm{C} 1$ minute & & \\
\hline \multirow[t]{3}{*}{ (5,8-ITS) } & TCTCAGGCTCCCTCTCCGGA & $55^{\circ} \mathrm{C} 1$ minute & 35 cycles & \\
\hline & & $72^{\circ} \mathrm{C} 1$ minute & & \\
\hline & & $72^{\circ} \mathrm{C} 10$ minutes & & \\
\hline \multirow[t]{2}{*}{ Algae } & AATCAGTTATAGTTTATTTGRTGGTACC & $94^{\circ} \mathrm{C} 5$ minutes & & $400 \mathrm{bp}$ \\
\hline & & $94^{\circ} \mathrm{C} 50$ seconds & & \\
\hline \multirow[t]{3}{*}{ (18S) } & TCTCAGGCTCCCTCTCCGGA & $57^{\circ} \mathrm{C} 50$ seconds & 37 cycles & \\
\hline & & $72^{\circ} \mathrm{C} 50$ seconds & & \\
\hline & & $72^{\circ} \mathrm{C} 10$ minutes & & \\
\hline
\end{tabular}

$2 \mu \mathrm{mol}$ of each primer, $10 \mu \mathrm{L}$ of GoTaq ${ }^{\circ}$ Green MasterMix (Promega), and $1 \mu \mathrm{L}(15 \mu \mathrm{g} / \mathrm{mL}$ ) of template DNA extracted from the soil samples were combined with $\mathrm{H}_{2} \mathrm{O}$ to a volume of $20 \mu \mathrm{L}$ in a $0.5-\mathrm{ml}$ test tube. To minimise non-specific annealing of the primers to non-target DNA, each amplification protocol was standardised as it is shown in Table 2. For each PCR amplification a specific positive control was used: IH9 culture (cyanobacteria), Klebsiella pneumoniae (fixing-nitrogen bacteria), Diaporthe australafricana (fungi), and Durvillaea antarctica (algae).

All amplified fragments were sequenced through Macrogen Illumina platform using specific primer sequences. All outputs were analysed via online alignment resources of BLAST (http://blast.ncbi.nlm.nih.gov/Blast.cgi) in order to obtain the diversity of cyanobacteria, fungi, algae and nitrogen-fixing bacteria genus in each location.

\subsection{Physicochemical and biological characterisation of soils}

The amount of sample used for the physicochemical analyses was dependant on the specific protocols. Water content was measured by weighing $1.0 \mathrm{~g}$ of sample before and after incubation for 72 hours at $50^{\circ} \mathrm{C}$. 
Conductivity and $\mathrm{pH}$ were measured using electrochemical methods. Each mix sample soil was blended with distilled water in a 1:5 ratio and was maintained for one hour in an orbital shaker at $20 \mathrm{rpm}$. The mixes were decanted for 10 minutes and parameters were measured in the liquid phase. Organic matter and organic carbon content were measured through colorimetric determination of reduced chromate mixing $0.5 \mathrm{~g}$ of the soil sample with sodium dichromate and sulphuric acid. The samples were blended and maintained overnight at room temperature and the absorbance at $600 \mathrm{~nm}$ was measured in a spectrophotometer UV-VIS (modified from Walkley \& Black 1934). For the quantification of elements, $100 \mathrm{mg}$ of soil samples from each sector were sieved (mesh size $2 \mathrm{~mm}$ ) and dried at $50^{\circ} \mathrm{C}$ for 72 hours in an oven. Then, the samples were microwave digested with a mix of $\mathrm{HNO}_{3}: \mathrm{HF}: \mathrm{HCl}$ in a ratio 3:1,5:1 for $36 \mathrm{~min}$, ending the digestion with $\mathrm{HBO}_{3}$. The samples were diluted with $40 \mathrm{~mL}$ of $\mathrm{H}_{2} \mathrm{O}$ milli $\mathrm{Q}$ and filtered. The elements were determined by ICP-OES using a multi-element standard solution (Merck) for the determination of $\mathrm{Al}, \mathrm{As}, \mathrm{Ca}, \mathrm{Cd}, \mathrm{Co}, \mathrm{Cr}, \mathrm{Cu}$, $\mathrm{Fe}, \mathrm{K}, \mathrm{Na}, \mathrm{Ni}, \mathrm{Mg}, \mathrm{Mn}, \mathrm{Pb}, \mathrm{Zn}$ (U.S. EPA 1996). The phosphatase enzymatic activity was determined by the method described by Tabatabai and Bremner (1969).

\section{$3 \quad$ Results}

\subsection{Molecular analysis of soil crust samples}

A summary of the intensity of amplicons obtained per location is shown in Table 3. All the soil samples at each site showed different intensities of amplicons for cyanobacteria. For nitrogen-fixing bacteria, fifteen DNA samples amplified a fragment associated to the nif gene, which encodes to a nitrogenase enzyme. The amplicon size was expected to be $370 \mathrm{bp}$ in length, but two samples were amplified for a bigger size fragment of about $800 \mathrm{bp}$. When the amplicons were sequenced, the sample presented identity with nitrogen-fixing bacteria, so it may be possible that there was amplification of a gene present in an operon called nifHDK, which gives an amplification of a bigger size than expected (Joerger et al. 2010). In addition, cyanobacteria can specialise in heterocysts, which are a morpho-functional specialisations to fix nitrogen and characterised by a filamentous formation. The genes involved in the nitrogen fixation in heterocyst is the nifHDK operon, and the amplification can yield two different size of fragments as in the case of sample A4 (Kumar et al. 2010; Hilton et al. 2013). The formation of heterocysts is associated to the filamentous structures in cyanobacteria as has been observed for the sample A (personal observations). The formation of heterocyst-type structures involves the ability of the biocrusts to supply nitrogen to the soils.

Table 3 Summary of amplified fragments intensity in the soil crust samples at each site

\begin{tabular}{ccccc}
\hline Site & Cyanobacteria & $\begin{array}{c}\text { Nitrogen-fixing } \\
\text { bacteria }\end{array}$ & Algae & Fungi \\
\hline A & 2 & 1 & 2 & 2 \\
\hline B & 1 & 1 & 1 & 0 \\
\hline C & 2 & 1 & 2 & 1 \\
D & 2 & 1 & 1 & 1 \\
\hline E & 1 & 0 & 1 & 1 \\
\hline F & 1 & 0 & 1 & 1 \\
\hline
\end{tabular}

1: smooth band; 2: strong band; 0: no amplification

On the other hand, the algae amplified fragment's size was according to the expected length (400 bp). This result demonstrates heterogeneity of the soil samples. Finally, 21 samples showed amplified fragment from ITS region of DNA of fungi. Several soil crust samples showed different size for the amplicons (data not shown). This observation is consistent with literature that explains that the ITS region in fungi is variable in length and composition for each species. It can be interpreted that soil samples, in which different bands for fungi detection appear present a high diversity of species. The observed biological heterogeneity in the 
soil samples, determined as the amplification of specific DNA fragments for cyanobacteria, nitrogen-fixing bacteria, fungi and algae is high. The lack of amplicons for organisms different from cyanobacteria can be an indicator of a differential maturity of the soil crusts. Thus, locations $A$ and $C$ could be representative of more mature crust as compared with locations $B$ and $E$, which have a poor heterogeneity, characteristic of young crusts (Lin et al. 2013).

\subsection{Diversity in bacterial rRNA}

The diversity of bacteria and cyanobacteria genus is observed in Figures 2(a) and (b). A high variability in all samples is shown. Locations A, B and D showed a high representation of Leptolyngbya and Oscillatoria genus for cyanobacteria; and Tolypothrix, Lyngybya, Cylindrspermum, Rodospirillum and Azospitillum genus for nitrogen-fixing bacteria. For the C, D and E locations, differences in cyanobacteria genus were observed, showing presence of Chroococcidiopsis, Cyanothece, Nostoc and Scitonema as the most representative. The most representative genres of nitrogen-fixing microorganisms were mostly cyanobacteria, which can be associated to the formation of heterocysts (nitrogen-fixing adaptations in cyanobacteria), according to the previous discussion (Kumar et al. 2010; Hilton et al. 2013).





(a)



Rhodospirillum
三 Azospirillum
敩 Skermanella
$\approx$ Rhodovulum
Nostoc
L Lyngybya
: Calothrix
\#Cylindrospermum
Scytonema
a Tolypothrix

(b)

Figure 2 Relative abundance of bacterial taxonomic groups at each location: (a) Cyanobacterial genus; (b) Nitrogen-fixing bacteria genus

\subsection{Diversity in eukaryotes rRNA}

The diversity of algae genus was observed in Figure 3(a). The highest diversity was observed in location A, which have six different algae genus in their BSCs composition. For the rest of the location analysed, we observed a high presence of genus Chlamydomonas, Radiococcus and Chlorella. 


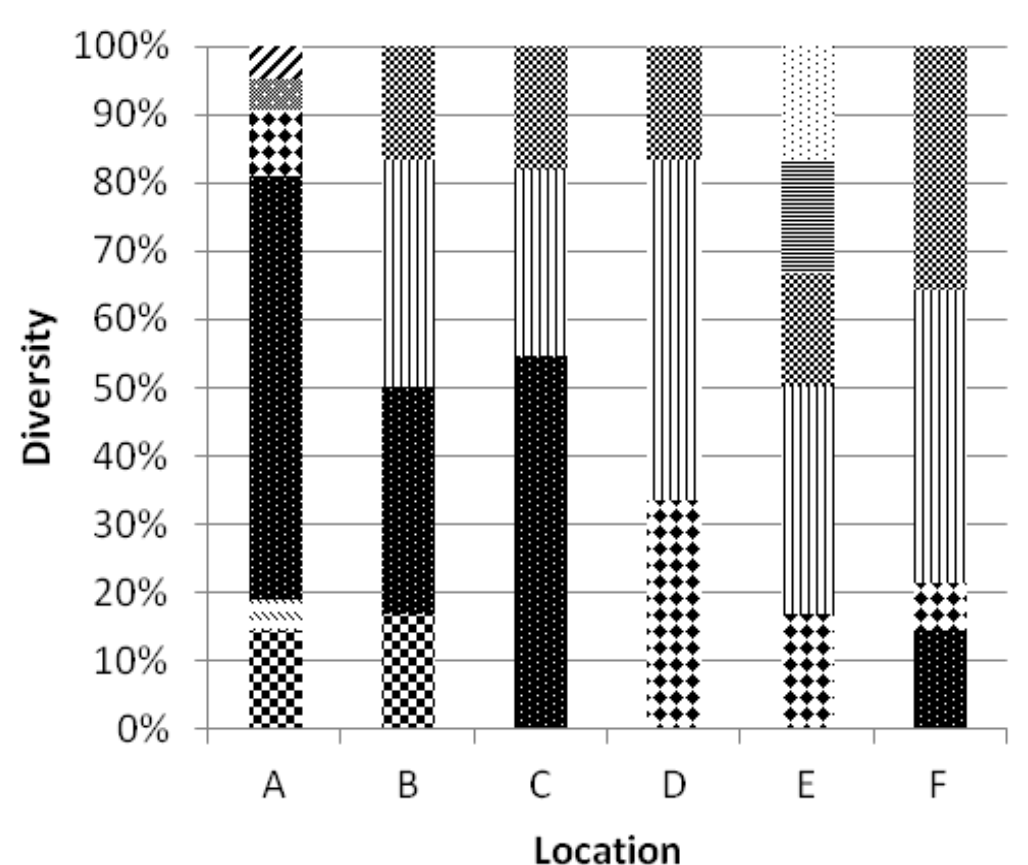

(a)



\section{Tetraspora}

豆 Lagerheimia

* Radiococcus

III Chlamydomonas

". Picocystis

Nephroselmis

-Chlorella

-8 (Ulothrix) Uronema

in Dictyochloropsis

$\mathbf{a}$ Trebouxia

\section{$\therefore$ Emericella \\ « Paraglomus \\ 三 Rutstroemia \\ Leotiomycetes \\ NPseudocercosporella \\ III Mycocentrospora \\ 言 Capnobotryella \\ 泳Lophiostoma \\ :Oedocephalum \\ Placidium \\ s Acarospora}

/. Stemphylium

(b)

Figure 3 Relative abundance of taxonomic groups of: (a) algae at each location; and (b) fungi at each location

Fungal diversity was higher than the algae diversity in the sites (Figure 3(b)). In the northern locations (A, B and $D$ ) we observed a prevalence of fungi belonging to the genus Capronia, Endocarpon, Capnobotryella and Lophiostoma. In the southern locations (C, E and F) we observed minor fungal diversity. The northern locations of the region ( $A, B$ and $D)$ present different climatic conditions than the southern locations $(C, E$ and $\mathrm{F}$ ) and this observation correlates with a higher variability of organisms in the northern sites as compared with the southern locations. This result is indicative of more matures BSCs in the soils (Yeager et al. 2004; CONAMA 2010). 
According to the literature, BSCs are formed in successional stages, and the presence of different microorganisms is an index of the stage of the maturity of the crust (Margrit et al. 2009). The presence of cyanobacteria is related to the formation and development of BSCs, and a high diversity of this type of microorganisms is related to an intermediate or mature soil crust. In parallel, the presence of different genus of eukaryotes organisms such as fungi and algae is correlated with a higher maturity of the BSC (Rozenstein \& Karnieli 2015; Darby et al. 2007).

\subsection{Physicochemical and biological soil characterisation}

The average percentage of humidity, electrical conductivity (EC), $\mathrm{pH}$, organic matter, organic carbon and alkaline phosphatase activity of soil samples for each site are shown in Table 4. For all sites, the pH values were according to the expected values reported as optimal for the development of biocrusts, which range between 6 to 8 (Weyman-Kaczmarkowa \& Pedziwilk 2000). EC, as an indirect measure for the salinity of the samples, showed moderate values in all sites independently of the geographical location. The Coquimbo region of Chile is characterised by a variable salinity in different locations, which is mostly related to the presence of elevated concentrations of calcium, sodium, carbonates and sulphates. In addition, these soils are poorly washed due to the limited rains in the arid climate of the region (CONAMA 2010; Drees et al. 2006). The contents of organic matter (OM) and organic carbon (OC) were higher than the expected for the soils of the region (Aguilera et al. 1998). The high values for organic compounds found in the samples might be due to the biological activity of BCSs (Maestre \& Cortina 2002). Finally, the alkaline phosphatase activities were higher than the expected for arid soils without vegetation, which are reported between 0.1 to $0.9 \mu \mathrm{mol}$ 4-nitrophenol g ${ }^{-1} \mathrm{~h}^{-1}$ (García et al. 1994).

Table 4 Humidity, conductivity and $\mathrm{pH}$ of mix samples per location. The results correspond to the average of 3 to 8 samples for each site and their standard error

\begin{tabular}{ccccccc}
\hline Location & $\begin{array}{c}\text { Humidity } \\
(\%)\end{array}$ & $\begin{array}{c}\mathrm{EC} \\
(\mathrm{mS} / \mathrm{m})\end{array}$ & $\mathbf{p H}$ & $\begin{array}{c}\text { Organic } \\
\text { matter } \\
(\%)\end{array}$ & $\begin{array}{c}\text { Organic } \\
\text { carbon } \\
(\%)\end{array}$ & $\begin{array}{c}\text { Alkaline } \\
\text { phosphatase } \\
\left(\boldsymbol{\mu} \mathbf{m o l ~}^{-1} \mathbf{h}^{-1}\right)\end{array}$ \\
\hline A & $1.0 \pm 0.29$ & $31.64 \pm 5.51$ & $7.67 \pm 0.08$ & $3.53 \pm 1.09$ & $2.05 \pm 0.63$ & $18.68 \pm 4.71$ \\
\hline B & $3.3 \pm 2.71$ & $26.26 \pm 9.11$ & $7.42 \pm 0.16$ & $1.30 \pm 0.09$ & $0.75 \pm 0.05$ & $4.10 \pm 3.65$ \\
\hline C & $1.5 \pm 0.36$ & $13.39 \pm 4.90$ & $7.06 \pm 0.15$ & $3.30 \pm 1.04$ & $1.92 \pm 0.61$ & $13.42 \pm 3.97$ \\
D & $4.7 \pm 2.40$ & $24.19 \pm 4.90$ & $7.54 \pm 0.14$ & $1.25 \pm 0.33$ & $1.25 \pm 0.33$ & $15.23 \pm 8.31$ \\
E & $1.6 \pm 0.46$ & $15.22 \pm 3.89$ & $7.34 \pm 0.04$ & $1.18 \pm 0.57$ & $1.18 \pm 0.57$ & $9.40 \pm 6.63$ \\
\hline F & $1.0 \pm 0.13$ & $16.50 \pm 2.28$ & $7.07 \pm 0.09$ & $1.26 \pm 0.38$ & $1.26 \pm 0.38$ & $14.05 \pm 7.95$ \\
\hline
\end{tabular}

The content of total elements in soils for each site is shown in the Table 5. The elevated amount of ions such as sodium or potassium agrees with the values of EC. Interestingly, the high levels of some metals such as $\mathrm{Mn}, \mathrm{Cu}$ and $\mathrm{Fe}$ were not restrictive for the establishment of the microorganisms in the soil. Particularly, the samples from sites $\mathrm{C}$ and $\mathrm{F}$ need to be studied more, because the amount of $\mathrm{Cu}, \mathrm{Mn}$ and $\mathrm{Zn}$ present is similar to the content of the metals found in copper mine sites. It is noted that the organic matter content and the neutral $\mathrm{pH}$ of the soils minimises the lixiviation of the elements from the soil and lower their bio-availability. 
Table 5 Total elements content at each location - the results correspond to the average of the samples for each site and their standard error

\begin{tabular}{ccccccc}
\hline Element & A & B & C & D & E & F \\
\hline Co & $17.7 \pm 0.6$ & $10.9 \pm 4.2$ & $17.7 \pm 1.7$ & $14.1 \pm 6.2$ & $21.5 \pm 12.6$ & $17.6 \pm 6.6$ \\
\hline Cu & $100.7 \pm 7.7$ & $17.56 \pm 5.6$ & $312.3 \pm 112$ & $32.27 \pm 4.61$ & $90.37 \pm 52.2$ & $94.99 \pm 35.9$ \\
\hline Cr & $40.2 \pm 0.9$ & $44.1 \pm 7.4$ & $23.5 \pm 1.9$ & $46.2 \pm 21$ & $35.5 \pm 20.5$ & $34.8 \pm 13.2$ \\
\hline Mn & $964.5 \pm 28.9$ & $747.5 \pm 229$ & $1,432 \pm 131$ & $900.0 \pm 394$ & $1,070 \pm 618$ & $1,146 \pm 433$ \\
\hline Ni & $19.2 \pm 0.5$ & $12.3 \pm 1.5$ & $13.5 \pm 1$ & $11 \pm 4.4$ & $21.9 \pm 12.7$ & $14.3 \pm 5.4$ \\
\hline Zn & $88.38 \pm 3.6$ & $41.81 \pm 14.4$ & $181.3 \pm 15.7$ & $73.51 \pm 16.1$ & $127 \pm 73.3$ & $115.7 \pm 43.7$ \\
\hline Cd & $<0.01$ & $<0.01$ & $<0.01$ & $<0.01$ & $<0.01$ & $0,06 \pm 0.02$ \\
\hline Pb & $<0.01$ & $<0.01$ & $11.14 \pm 6.5$ & $<0.01$ & $<0.01$ & $30.73 \pm 11.6$ \\
\hline Fe & $44,753 \pm 1$ & $30,261 \pm 15,702$ & $48,994 \pm 3,248$ & $48,863 \pm 22,493$ & $52,883 \pm 30,532$ & $60,749 \pm 22,961$ \\
\hline K & $15,471 \pm 284$ & $11,075 \pm 2,778$ & $12,694 \pm 2,635$ & $11,738 \pm 3,855$ & $8,081 \pm 4,666$ & $15,318 \pm 5,790$ \\
\hline Mg & $9,777 \pm 633$ & $4,562 \pm 447$ & $4,624 \pm 1,336$ & $4,171 \pm 1,152$ & $8,923 \pm 5,152$ & $8,076 \pm 3,052$ \\
\hline Na & $22,827 \pm 322$ & $17,566 \pm 5,998$ & $23,476 \pm 1,165$ & $16,278 \pm 6,426$ & $17,516 \pm 10,113$ & $22,123 \pm 8,362$ \\
\hline Ca & $29,607 \pm 721$ & $39,631 \pm 10,538$ & $15,450 \pm 2,003$ & $24,557 \pm 4,362$ & $24,278 \pm 14,017$ & $30,964 \pm 11,703$ \\
\hline Al & $54,008 \pm 1,849$ & $35,857 \pm 13,586$ & $39,384 \pm 4,873$ & $29,625 \pm 13,098$ & $57,095 \pm 32,964$ & $55,655 \pm 21,036$ \\
\hline & & & & & & \\
\hline
\end{tabular}

\section{Conclusion}

Microbial diversity of populations forming biological crusts at six locations from the Coquimbo region of Chile was determined through the study of the diversity of DNA amplicons obtained from soil crust samples. The samples analysed have a different microbial composition, and the microbiological biodiversity in the soil crusts can be used as an indicator of different levels of maturity of the biocrusts. The most mature and diverse BSCs were samples from location A. The micro-heterogeneity of the soil crust samples of nearby sites is evident and there is not a pattern in the microbial composition of the samples. We did not observe a direct relationship between the microbial signature determined and the physicochemical characteristics of the soils where the samples were obtained. However, the highest diversity of microorganism coincides with climate coastal location that has a higher humidity than the inland locations. The next step is a more detailed characterisation of the phylogeny and diversity of the soil crusts samples through massive sequencing, and the evaluation of the effect of the growth of the biocrusts on soil samples under controlled conditions. All together we will end with a methodology to cultivate, inoculate and optimise the growth of biocrust communities on soils in order to establish the first succession stage for mine site rehabilitation.

\section{Acknowledgement}

The work was sponsored by FONDEF-Chile ID 14L10151.

\section{References}

Aguilera, LE, Gutiérrez, JR \& Moreno, RJ 1998, 'Vesiculo arbuscular mycorrhizae associated with saltbushes Atriplex spp. (Chenopodiaceae) in the Chilean arid zone', Revista Chilena de Historia Natural, vol. 71, pp. 291-302.

Belnap, J \& Gillete, DA 1998, 'Vulnerability of desert biological soil crust to wind erosion: the influences of crust development, soil texture, and disturbance', Journal of Arid Environments, vol. 39, pp. 133-142.

Belnap, J \& Lange, OL 2003, Biological Soil Crusts: Structure, Function, and Management, Springer, Berlin, Heidelberg, First Edition, p. 506. 
Bérard, A \& Dorigo, U 2004, 'Microalgae community structure analysis based on 18S rDNA amplification from DNA extracted directly from soil as a potential soil bioindicator', Agronomie, pp. 1-7.

Bowker, M 2007, 'Biological Soil Crust Rehabilitation in Theory and Practice: An Underexploited Opportunity', Restoration Ecology, vol. 15, pp. 13-23.

Bowker, M \& Maestre, F 2014, 'Biological soil crusts (biocrusts) as a model system in community, landscape and ecosystem ecology', Biodiversity and Conservation, pp. 1619-1637.

Bowker, M, Maestre, F \& Soliveres, S 2010, 'Competition increases with abiotic stress and regulates the diversity of biological soil crusts', Journal of Ecology, vol. 98, pp. 551-560.

Bowker, MA, Mau, RL, Maestre, FT, Escolar, C \& Castillo-Monroy, AP 2011, 'Functional profiles reveal unique ecological roles of various biological soil crust organisms', Functional Ecology, vol. 25, pp. 787-795.

Castillo-Monroy, AP, Maestre, FT, Delgado-Baquerizo, M \& Gallardo, A 2010, 'Biological soil crusts modulate nitrogen availability in semi-arid ecosystems: insights from a Mediterranean grassland', Plant and Soil, vol. 333, pp. 21-34.

CONAMA 2010, 'De mar a cordillera: Cuarta Región de Coquimbo', Ediciones Gobierno de Chile, vol. 1, pp. 20-65.

Darby, B, Neher, D \& Belnap, J 2007, 'Soil nematode communities are ecologically more mature beneath late- than early-successional stage biological soil crusts', Applied Soil Ecology, vol. 35, pp. 203-212.

Drees, K, Neilson, J, Betancourt, J, Quade, J, Henderson, D, Pryor, B \& Maier, R 2006 'Bacterial community structure in the hyperarid core of the Atacama Desert, Chile', Applied and Environmental Microbiology, vol. 72, no. 12, pp. 7902-7908.

Eldridge, D 1996, 'Cryptogamic soil crusts: fixers of the desert', in Proceedings of the 1996 Workshop on rehabilitation of arid and semi-arid lands, Goldfields Land Rehabilitation Group, Boulder, WA, pp. 87-92.

García-Pichel, F \& Lopez, A 2001, 'Phylogenetic and morphological diversity of cyanobacteria in soil desert crusts from the Colorado plateau', Applied an Enviromental Microbiology, vol. 67, no. 4, pp. 1902-1910.

García, C, Hernández, T \& Costa, F 1994, 'Microbial Activity in Soils under Mediterranean Environmental Conditions', Soil Biology \& Biochemistry, vol. 26, pp. 1185-1191.

Hilton, J, Foster, R, Tripp, J, Carter, B, Zehr, J \& Villarreal, T 2013, 'Genomic deletions disrupt nitrogen metabolism pathways of a cyanobacterial diatom symbiont', Nature Communications, vol. 4:1767, pp. 1-7.

Joerger, R, Wolfinger, E \& Bishop, P 2010, 'The gene encoding dinitrogenase reductase 2 is required for expression of the second alternative nitrogenase from Azotobacter vinelandii', Journal of Bacteriology, vol. 173, no. 14, pp. 4440-4446.

Komárek, J, Sant'Anna, CL, Bohunicka, M, Mares, J, Hentschke, GS, Rigonato, J \& Fiore, MF 2013, 'Phenotype diversity and phylogeny of selected Scytonema-species (Cyanoprokaryota) from SE Brazil', Fottea, vol. 13, pp. 173-200.

Kumar, K, Mella-Herrera, R \& Golden, J 2010, 'Cyanobacterial heterocysts', Cold Spring Harbor Perspectives in Biology, vol. 2:a000315, pp. 1-20.

Lin, C, Chou, T \& Wu, J 2013, 'Biodiversity of soil algae in farmlands of mid-Taiwan', Botanical Studies, no. 54, pp. 1-12.

Maestre, FT \& Cortina, J 2002, 'Small-scale spatial variation in soil $\mathrm{CO}_{2}$ efflux in a Mediterranean semiarid steppe', Applied Soil Ecology, vol. 23, pp. 199-209.

Margrit, T, Storm, C \& Schwabe, A 2009, 'Community assembly of biological soil crusts of different successional stages in a temperate sand ecosystem, as assessed by direct determination and enrichment techniques', Microbial Ecology, vol. 58, no. 2, pp. 394-407.

Rodicio, M \& Mendoza, M 2004, 'Identificación bacteriana mediante secuenciación del ARNr 16S: fundamento, metodología y aplicaciones en microbiología clínica', Enfermedades Infecciosas y Microbiología Clínica, vol. 22, no. 04, p. 81.

Rozenstein, O \& Karnieli, A 2015, 'Identification and characterization of Biological Soil Crusts in a sand dune desert environment across Israel-Egypt border using LWIR emittance spectroscopy', Journal of Arid Environments, vol. 112, pp. 75-86.

Schoch, C, Seifert, K, Huhndorf, S, Vincent, R \& Levesque, A 2012, 'Nuclear ribosomal internal transcribed spacer (ITS) region as a universal DNA barcode marker for Fungi', PNAS, vol. 109, no. 16, pp. 6241-6246.

Tabatabai, M \& Bremner, J 1969, 'Use of p-nitrophenyl phosphate for assay of soil phosphatase activity' Great Britain: Pergamon Pres, Soil Biology and Biochemistry, vol. 1, pp. 301-307.

U.S. EPA (United States Environmental Protection Agency) 1996, Method 3050B. Acidic digestion of sediments, sludges, and soils, viewed 2 December 2015, http://www3.epa.gov/epawaste/hazard/testmethods/sw846/pdfs/3050b.pdf

Valentini, A, Pompanon, F \& Taberlet, P 2009, 'DNA barcoding for ecologists', Trends in Ecology and Evolution, vol. 24, pp. 110-117.

Walkley, A \& Black, LA 1934, 'An examination of the Degtjareff method for determining organic carbon in soils: Effect of variations in digestion conditions and of inorganic soil constituents', Soil Science, vol. 63, pp. 251-263.

Wei, JC 2005, 'Biocarpet engineering using microbiotic crust for controlling sand', Arid Zone Research, vol. 22, pp. $287-288$.

Weyman-Kaczmarkowa, W \& Pedziwilk, Z 2000, 'The development of fungi as affected by pH and type of soil, in relation to the occurrence of bacteria and soil fungistatic activity', Microbiological Research, vol. 155, no. 2, pp. 107-112.

Yeager, C, Kormosky, J \& Housman, D 2004, 'Diazotrophic Community Structure and Function in Two Successional Stages of Biological Soil Crusts from the Colorado Plauteau and Chihuahuan Desert', Applied Environmental Microbiology, vol. 70, no. 2, pp. 973-983.

Zaady, E, Gutterman, Y \& Boeken, B 1997 'The germination of mucilaginous seed of Plantago coronopus, Reboudia pinnata, and Carrichtera annua on cyanobacterial soil crust from the Negev Desert', Plant and Soil, vol. 190, pp. 247-252.

Zhang, YM, Wang, HL, Wang, XQ, Yang, WK \& Zhang, DY 2006, 'The microstructure of microbiotic crust and its influence on wind erosion for a sandy soil surface in the Gurbantunggut Desert of Northwestern China', Geoderma, vol. 132, issue 3-4, pp. 441-449. 